\title{
Pengaruh Good Corporate Governance Mechanism Terhadap Nilai Perusahaan pada Perusahaan di Bursa Efek Indonesia
}

\author{
Made Reina Candradewi
}

Universitas Udayana

\begin{abstract}
ABSTRAK
Persaingan global yang semakin ketat, menjadikan nilai perusahaan semakin penting untuk diperhatikan. Perusahaan harus mampu mempertahankan nilainya agar mampu bersaing di era globalisasi. Penelitian ini bertujuan untuk menganalisis pengaruh good corporate governance mechanism, yang terdiri dari kepemilikan manajerial, kepemilikan institusional, proporsi komisaris independen, ukuran dewan komisaris dan komite audit, terhadap nilai perusahaan. Populasi dalam penelitian ini adalah seluruh perusahaan yang sahamnya terdaftar dalam indeks LQ45 di Bursa Efek Indonesia pada tahun 2016. Teknik penentuan sampel yaitu dengan purposive sampling method, sehingga sampel akhir pada penelitian ini adalah 44 perusahaan. Teknik analisis data yang digunakan dalam penelitian ini adalah analisis regresi linear berganda. Temuan utama penelitian menunjukkan bahwa kepemilikan institusional berpengaruh secara positif dan signifikan terhadap nilai perusahaan.
\end{abstract}

Kata kunci: corporate governance, nilai perusahaan

Klasifikasi JEL: G34, G32

\section{The Effect of Good Corporate Governance Mechanism on Firm Value in Indonesian Stock Exchange Listed Companies}

\begin{abstract}
The increasing global competition, makes the firm value more important to be taken into account. Companies must be able to maintain its value in order to compete in the era of globalization. This study aims to analyze the influence of good corporate governance mechanism, which consists of managerial ownership, institutional ownership, proportion of independent commissioner, board size and audit committee, to the firm value. The population in this study are all companies whose shares are listed in the LQ45 index in Indonesia Stock Exchange in 2016. The technique of determining the sample is purposive sampling method, thus the final sample in this study is 44 companies. Data analysis technique employed in this research is multiple linear regression analysis. The main findings of the study indicates that institutional ownership positively and significantly affects firm value.
\end{abstract}

Keywords: corporate governance, firm value

JEL classification: $G 34$, G32

\section{PENDAHULUAN}

Globalisasi dan liberalisasi dunia memberi dampak semakin kuatnya persaingan yang terjadi antar perusahaan. Globalisasi dunia membuat perekonomian dunia lebih erat keterkaitannya. Liberalisasi dunia menyebabkan terbukanya pasar domestik terhadap investor asing, sehingga hambatan antar negara berkurang dan aliran modal menjadi lebih mudah untuk masuk dan keluar. Hal ini menyebabkan meningkatnya persaingan antar perusahaan, tidak hanya domestik namun secara global. Untuk mampu menghadapi persaingan global yang semakin ketat, perusahaan harus meningkatkan kinerjanya yang tercermin dari nilai perusahaan. Nilai perusahaan merupakan faktor penting bagi perusahaan, karena tujuan utama suatu perusahaan adalah untuk meningkatkan nilai perusahaan. Horne dan Wachowicz (2012) menyatakan bahwa, tujuan utama perusahaan adalah tidak semata-mata untuk memaksimalkan kekayaan pemegang saham, namun untuk dapat memaksimalkan nilai perusahaan.

Perusahaan dalam menjalani proses untuk memaksimalkan nilai perusahaan dihadapkan 
pada agency conflict, konflik kepentingan antara pemilik dan manajemen perusahaan, dimana corporate governance dipercaya mampu menjadi solusi untuk masalah tersebut. Penerapan good corporate governance memiliki tujuan utama untuk meningkatkan efisiensi dan efektivitas kerja manajemen perusahaan, melindungi hak dan kepentingan pemegang saham dan meningkatkan nilai perusahaan (Sutojo dan Aldridge, 2008). Menurut Trinh et al (2015), corporate governance memiliki internal mechanism yang terdiri dari ownership structure dan management structure. Dengan demikian beberapa hal penting yang perlu diperhatikan dalam corporate governance adalah kepemilikan manajerial, kepemilikan institusional, proporsi komisaris independen, ukuran dewan komisaris dan komite audit.

Corporate governance dan nilai perusahaan telah menjadi persoalan yang cukup penting bagi perusahaan di seluruh dunia. Beberapa penelitian menemukan adanya ketidakjelasan hubungan antara pelaksanaan good corporate governance dengan nilai perusahaan yang lebih tinggi, karena biaya yang terkait dengan penerapan corporate governance mechanism dapat melampaui manfaatnya (Chhaochharia dan Grinstein, 2007; Bruno dan Claessens, 2010). Namun, penelitian empiris oleh Gompers et al (2003), Cremers dan Nair (2005), Core et al (2006), Bebchuck et al (2009) dan Eberhart (2012) menemukan adanya hubungan positif antara penerapan corporate governance yang baik dengan nilai perusahaan. Perbedaan hasil penelitian terdahulu ini, menyebabkan pentingnya untuk diteliti kembali mengenai bagaimana corporate governance berpengaruh terhadap nilai perusahaan. Selain itu, analisis mendalam mengenai penerapan corporate governance di Indonesia sangat diperlukan. Hingga saat ini masih sedikit penelitian di Indonesia yang mengkaji corporate governance mechanism terhadap nilai perusahaan. Berbeda dengan penelitian terdahulu, penelitian ini menggunakan good corporate governance mechanism dengan memperhatikan dari segi ownership structure dan management structure secara komprehensif.

Objek penelitian dalam penelitian ini adalah perusahaan yang terdaftar dalam indeks LQ45 di BEI pada tahun 2016. Perusahaan yang terdaftar dalam indeks LQ45 yang dipilih dalam penelitian ini karena perusahaan tersebut merupakan perusahaan yang memiliki saham unggulan di BEI dengan nilai likuiditas dan kapitalisasi pasar tinggi. Dengan menggunakan perusahaan ini sebagai sampel maka akan diketahui bagaimana nilai perusahaan unggulan di BEI yang dipengaruhi oleh good corporate governance mechanism. Metode penelitian yang digunakan dalam penelitian ini adalah metode kuantitatif dengan menggunakan analisis regresi berganda. Hal ini sejalan dengan penelitian sebelumnya oleh Mishra dan Mohanty (2014), Siahaan (2013) dan Susanti (2014), yang menggunakan analisis regresi berganda.

Corporate governance merupakan suatu struktur yang terdiri dari pemegang saham, dewan direksi, dewan komisaris, dan hirarki manajerial perusahaan (Ogden, 2003). Corporate governance ini melibatkan serangkaian hubungan antara pemegang saham, dewan direksi, dewan komisaris, manajemen dan pemangku kepentingan lainnya (OECD, 2014). Fungsi corporate governance adalah untuk memacu penggunaan sumber daya perusahaan secara efisien dimana sangat diperlukan akuntabilitas dalam pengelolaan sumber daya tersebut (Osuoha, 2013). Selain itu, tujuan utama penerapan corporate governance adalah untuk menciptakan nilai tambah bagi para pemangku kepentingan atau stakeholders (FCGI, 2016). Good corporate governance mechanism yang penting untuk diperhatikan adalah dari segi kepemilikan yang meliputi kepemilikan manajerial dan kepemilikan institusional, dan dari segi manajemen yang meliputi proporsi komisaris independen, ukuran dewan komisaris dan komite audit.

Kepemilikan saham manajerial merupakan proporsi saham biasa yang dimiliki oleh para manajemen, yang dapat diukur dari persentase saham biasa yang dimiliki oleh pihak manajemen yang secara aktif terlibat dalam pengambilan keputusan perusahaan. Teori corporate governance oleh Jensen dan Meckling (1976) menyatakan bahwa, kepemilikan manajerial merupakan isu penting dalam teori corporate governance, teori ini menjelaskan bahwa semakin besar proporsi kepemilikan manajerial dalam suatu perusahaan maka manajemen akan berupaya lebih giat untuk memenuhi kepentingan pemegang saham yang juga adalah dirinya sendiri. Tujuan pemegang saham adalah untuk memaksimalkan nilai perusahaan. Oleh karena itu, semakin meningkatnya kepemilikan manajerial pada suatu perusahaan, maka para manajemen perusahaan 
yang juga sebagai pemegang saham akan lebih aktif untuk mewujudkan tujuan perusahaan untuk memaksimalkan nilai perusahaan.

Penelitian terdahulu, oleh Susanti et al (2010) menemukan adanya hubungan yang positif antara kepemilikan manajerial dan nilai perusahaan. Selain itu, Sofyaningsih dan Hardiningsih (2011) menjelaskan bahwa kepemilikan manajerial memiliki pengaruh yang positif dan signifikan terhadap nilai perusahaan, karena kepemilikan manajerial merupakan suatu mekanisme yang sangat efektif dalam mengatasi konflik keagenan yang terjadi di perusahaan. Penelitian oleh Susanti (2014) juga menemukan hubungan yang positif dan signifikan terhadap nilai perusahaan. Oleh karena itu, dapat dirumuskan hipotesis sebagai berikut:

Hipotesis 1: Kepemilikan manajerial berpengaruh positif dan signifikan terhadap nilai perusahaan.

Kepemilikan Institusional merupakan proporsi saham perusahaan yang dimiliki oleh institusi atau lembaga, seperti bank, perusahaan asuransi, perusahaan investasi atau institusi lainnya. Kepemilikan institusional memiliki peran yang sangat penting yaitu sebagai monitoring agent, yang melaksanakan pengawasan optimal terhadap perilaku manajemen dalam menjalankan perannya mengelola perusahaan (Sugiarto, 2011). Tingkat kepemilikan institusional yang tinggi akan menciptakan usaha pengawasan yang lebih besar oleh pihak investor institusional, sehingga dapat menghalangi perilaku opportunistic manajer.

Selain itu, Jensen dan Meckling (1976) menyatakan bahwa kepemilikan institusional memiliki peranan yang sangat penting dalam meminimalisasi konflik keagenan yang terjadi antara pemegang saham dan manajer. Kepemilikan institusional merupakan salah satu alat yang dapat digunakan untuk mengurangi agency conflict. Semakin tinggi tingkat kepemilikan institusional maka semakin kuat tingkat pengendalian yang dilakukan oleh pihak eksternal terhadap perusahaan sehingga agency conflict yang terjadi di dalam perusahaan akan semakin berkurang dan nilai perusahaan akan semakin meningkat.

Penelitian terdahulu, oleh Nuraina (2012) menyimpulkan bahwa kepemilikan institusional berpengaruh secara positif dan signifikan terhadap nilai perusahaan. Selain itu, hasil penelitian oleh Fauzan (2012) menyatakan bahwa kepemilikan institusional berpengaruh positif terhadap nilai perusahaan. Sukirni (2012) juga menyatakan bahwa kepemilikan institusional berpengaruh positif pada nilai perusahaan, karena besarnya kepemilikan institusional meningkatkan efisiensi pemanfaatan aktiva perusahaan. Dengan demikian dapat dirumuskan hipotesis sebagai berikut.

Hipotesis 2: Kepemilikan institusional berpengaruh positif dan signifikan terhadap nilai perusahaan.

Proporsi Komisaris Independen merupakan suatu proksi yang dapat digunakan untuk mengukur tingkat independensi dewan komisaris duatu perusahaan. Proporsi komisaris independen merupakan perbandingan antara jumlah anggota komisaris independen dengan komisaris yang berasal dari dalam perusahaan. Ketika suatu perusahaan memiliki proporsi komisaris independen yang lebih tinggi, dewan komisaris akan mampu untuk melakukan pengawasan dan memberikan nasihat kepada dewan direksi secara lebih efektif karena komisaris independen bekerja dengan profesional (Debby et al, 2014). Oleh karena itu, adanya komisaris independen pada perusahaan, akan membantu manajemen perusahaan untuk berkinerja dengan lebih baik sehingga nilai perusahaan pun meningkat.

Penelitian terdahulu oleh Siallagan Machfoedz (2006) menemukan bahwa tata kelola perusahaan, meliputi proporsi komisaris independen memiliki pengaruh yang positif terhadap nilai perusahaan. Selain itu, penelitian oleh Kumar dan Singh (2012) komisaris independen berpengaruh secara positif terhadap nilai perusahaan. Oleh karena itu dapat dirumuskan hipotesis sebagai berikut:

Hipotesis 3: Komisaris independen berpengaruh positif dan signifikan terhadap nilai perusahaan.

Corporate governance merupakan suatu mekanisme yang digunakan untuk menurunkan konflik keagenan yang terjadi antara pihak manajemen dan pemegang saham (Jensen dan Meckling, 1976). Dewan komisaris memiliki tugas untuk melakukan pengawasan dan memberikan nasihat kepada dewan direksi. Ketika perusahaan memiliki ukuran dewan komisaris lebih tinggi, maka dewan komisaris akan mampu untuk melaksanakan tugas pengawasan dengan lebih baik, sehingga manajemen perusahaan akan memiliki kinerja lebih baik dan pada nantinya nilai perusahaan dapat meningkat. Penelitian oleh Siahaan (2013) menemukan adanya hubungan yang positif antara ukuran dewan komisaris 
dan nilai perusahaan. Selain itu, Penelitian oleh Siallagan dan Machfoedz (2006) juga menyatakan bahwa dewan komisaris berpengaruh secara positif terhadap nilai perusahaan. Dengan demikian dapat dirumuskan hipotesis sebagai berikut:

Hipotesis 4: Ukuran dewan komisaris berpengaruh positif dan signifikan terhadap nilai perusahaan.

Komite audit merupakan bagian dari perusahaan yang dibentuk oleh dewan komisaris untuk melaksanakan tugas dalam mengawasi manajemen perusahaan. Terbentuknya komite audit sangat penting bagi perusahaan karena komite audit merupakan komponen baru dalam sistem corporate control. Peran komite audit dalam mengobservasi dan mengawasi kinerja manajemen perusahaan, akan berpengaruh positif terhadap nilai perusahaan.

Penelitian oleh Siallagan dan Machfoedz (2006) menemukan adanya hubungan yang positif antara komite audit dan nilai perusahaan. Selain itu, penelitian oleh Animah (2008) juga menyatakan bahwa komite audit berpengaruh secara positif terhadap nilai perusahaan. Oleh karena itu dapat dirumuskan hipotesis sebagai berikut:

Hipotesis 5: Komite audit berpengaruh positif dan signifikan terhadap nilai perusahaan.

\section{DATA DAN METODE PENELITIAN}

Penelitian menggunakan rancangan kausalitas untuk membuktikan hubungan antara sebab dan akibat dari beberapa variabel. Penelitian ini dirancang untuk mengetahui pengaruh tingkat kepemilikan manajerial, kepemilikan institusional, proporsi komisaris independen dan komite audit terhadap nilai perusahaan. Objek penelitian adalah perusahaan yang terdaftar dalam indeks LQ45 di BEI tahun 2016. Jenis data dalam penelitian ini adalah data kuantitatif. Selain itu, penelitian ini menggunakan data sekunder, dimana seluruh data diperoleh dari laporan keuangan tahunan masing-masing perusahaan yang dipublikasikan pada website Bursa Efek Indonesia. Populasi dalam penelitian ini adalah seluruh perusahaan yang terdaftar dalam indeks LQ45 di BEI pada tahun 2016. Teknik penentuan sampel dalam penelitian ini adalah purposive sampling method. Kriteria pengambilan sampel yang digunakan dalam penelitian ini adalah perusahaan yang sahamnya selalu muncul dalam indeks LQ45 pada periode pertama dan periode kedua tahun 2016. Berdasarkan kriteria tersebut, maka diperoleh 44 perusahaan yang memenuhi kriteria sampel.

Analisis data pertama yang dilakukan dalam penelitian ini adalah statistik deskriptif. Statistik deskriptif dalam penelitian ini melakukan perhitungan rata-rata, standar deviasi, persentase dari data sampel untuk seluruh variabel dengan data rasio. Analisis data kedua yang dilakukan dalam penelitian ini adalah analisis inferensial. Analisis inferensial digunakan untuk menguji hipotesis yang diformulasikan dalam penelitian ini. Teknik analisis inferensial yang dilakukan dalam penelitian ini adalah analisis regresi linier berganda untuk menguji Hipotesis 1 sampai dengan Hipotesis 5 dengan menggunakan program SPSS

\section{HASIL DAN PEMBAHASAN}

Analisis statistik deskriptif dilakukan untuk memberikan gambaran atau deskripsi mengenai variabel penelitian yang terdiri dari Nilai Perusahaan (Y), Kepemiilikan Manajerial $\left(\mathrm{X}_{1}\right)$, Kepemilikan Institusional $\left(\mathrm{X}_{2}\right)$, Proporsi Komisaris Independen $\left(\mathrm{X}_{3}\right)$, Ukuran Dewan Komisaris $\left(\mathrm{X}_{4}\right)$ dan Komite Audit $\left(\mathrm{X}_{5}\right)$ melalui nilai rata-rata (mean), nilai maksimum, nilai minimum dan standar deviasi. Statistik deskriptif selengkapnya dapat dilihat pada Tabel 1 .

Sebelum dilakukan pengujian terhadap hipotesis yang diajukan, terlebih dahulu dilakukan Uji Asumsi Klasik terhadap data yang digunakan. Uji Normalitas bertujuan untuk menguji sejauh mana distribusi data sampel berkorespondensi terhadap distribusi normal (Hair et al., 2006:40). Dalam model regresi, Uji $\mathbf{t}$ dan Uji $\mathbf{F}$ statistik mengasumsikan bahwa nilai residual mengikuti distribusi normal (Gujarati \& Porter, 2009: 99). Pengujian normalitas data dalam studi ini dilakukan dengan metode Kolmogorov-Smirnov (K-S). Hasil uji normalitas pertama menunjukkan nilai asymp. Sig (2-tailed) sebesar $0.000(\mathrm{p}<0,05)$. Ini mengindikasikan adanya distribusi data tidak normal, sehingga data belum dapat digunakan untuk analisis regresi selanjutnya. Langkah berikutnya yaitu mengidentifikasi outliers dalam data penelitian ini. Teramati bahwa terdapat dua outliers dalam penelitian ini yaitu sample ke 25 (PT Matahari Departement Store Tbk) dengan unstandardized residual sebesar 27,96 dan sampel ke 42 (PT Unilever Indonesia Tbk) dengan unstandardized residual sebesar 32,73. Kedua outliers ini dihilangkan sehingga data 
Tabel 1. Statistik Deskriptif Variabel Penelitian

\begin{tabular}{llcccc}
\hline & $\mathrm{N}$ & Minimum & Maksimum & Rata-rata & Standar Deviasi \\
\hline $\mathrm{Y}$ & 44 & .56 & 46.67 & 4.5718 & 8.07933 \\
$\mathrm{X}_{1}$ & 44 & .00 & 13.32 & .6206 & 2.55053 \\
$\mathrm{X}_{2}$ & 44 & 11.58 & 98.84 & 51.0470 & 20.15240 \\
$\mathrm{X}_{3}$ & 44 & .29 & .80 & .4349 & .12656 \\
$\mathrm{X}_{4}$ & 44 & 3.00 & 12.00 & 5.9091 & 1.99788 \\
$\mathrm{X}_{5}$ & 44 & 2.00 & 7.00 & 3.5455 & 1.04447 \\
\hline
\end{tabular}

Sumber: data sekunder diolah

Tabel 2. Hasil Uji Normalitas

\begin{tabular}{llc}
\hline & & Unstandardized Residual \\
\hline $\mathrm{N}$ & Mean & 42 \\
Normal Parameters ${ }^{a, b}$ & Standard Deviation & 0 \\
& Absolute & 1.006 \\
Most Extreme Differences & Positive & 0.075 \\
& Negative & 0.075 \\
Kolmogorov-Smirnov Z & & -0.041 \\
Asymp. Sig. (2-tailed) & & 0.117 \\
\hline
\end{tabular}

Sumber: data sekunder diolah

Tabel 3. Hasil Uji Autokorelasi

\begin{tabular}{llllll}
\hline Model & $R$ & $R$ Square & $\begin{array}{c}\text { Adjusted } R \\
\text { Square }\end{array}$ & $\begin{array}{c}\text { Std. Error of the } \\
\text { Estimate }\end{array}$ & $\begin{array}{c}\text { Durbin- } \\
\text { Watson }\end{array}$ \\
\hline 1 & $.486^{\text {a }}$ & .236 & .130 & 2.42834 & 1.870 \\
\hline Sumber: data sekunder diolah
\end{tabular}

Tabel 4. Hasil Uji Multikolinearitas

\begin{tabular}{lcc}
\hline \multicolumn{1}{c}{ Variabel } & Tolerance & VIF \\
\hline Kepemilikan Manajerial & .865 & 1.157 \\
Kepemilikan Institusional & .866 & 1.155 \\
Proporsi Komisaris Independen & .906 & 1.104 \\
Ukuran Dewan Komisaris & .821 & 1.218 \\
Komite Audit & .863 & 1.158 \\
\hline
\end{tabular}

Sumber: data sekunder diolah

Tabel 5. Hasil Uji Heteroskedastisitas

\begin{tabular}{ll}
\hline Variabel & Sig. \\
\hline (Constant) & .719 \\
Kepemilikan Manajerial & .654 \\
Kepemilikan Institusional & .111 \\
Proporsi Komisaris Independen & .465 \\
Ukuran Dewan Komisaris & .923 \\
Komite Audit & .413 \\
\hline
\end{tabular}


Tabel 6. Hasil Analisis Regresi Linear Berganda

\begin{tabular}{|c|c|c|c|c|c|}
\hline \multirow{2}{*}{ Model } & \multicolumn{2}{|c|}{$\begin{array}{l}\text { Unstandardized } \\
\text { Coefficients }\end{array}$} & \multirow{2}{*}{$\begin{array}{c}\text { Standardized } \\
\text { Coefficients } \\
\text { Beta }\end{array}$} & \multirow{2}{*}{$\mathrm{t}$} & \multirow{2}{*}{ Sig. } \\
\hline & $B$ & $\begin{array}{l}\text { Std. } \\
\text { Error }\end{array}$ & & & \\
\hline (Constant) & .477 & 1.317 & & .362 & .719 \\
\hline Kepemilikan Manajerial & .039 & .087 & .066 & .452 & .654 \\
\hline Kepemilikan Institusional & .046 & .012 & .549 & 3.744 & .001 \\
\hline $\begin{array}{l}\text { Proporsi Komisaris } \\
\text { Independen }\end{array}$ & -1.420 & 1.922 & -.106 & -.739 & .465 \\
\hline Ukuran Dewan Komisaris & .011 & .117 & .015 & .097 & .923 \\
\hline Komite Audit & -.177 & .213 & -.122 & -.827 & .413 \\
\hline R Square & & & & & \\
\hline Adjusted R Square $=0,236$ & & & & & \\
\hline$=3.539$ & & & & & \\
\hline$=0,011$ & & & & & \\
\hline
\end{tabular}

Sumber: data sekunder diolah

dapat digunakan untuk analisis selanjutnya. Hasil uji normalitas kedua yang ditampilkan pada Tabel 2 menunjukkan nilai asymp. Sig (2-tailed) sebesar 0,065 $(p>0,05)$. Ini mengindikasikan adanya distribusi data normal, sehingga data dapat digunakan untuk analisis regresi selanjutnya.

Uji autokorelasi digunakan untuk menguji apakah dalam model regresi terdapat korelasi antara residual pada periode $\mathbf{t}$ dengan residual pada periode t-1 (sebelumnnya) (Utama, 2012:103). Hasil uji autokorelasi melalui nilai Durbin Watson adalah 1,870 (Tabel 3). Hasil ini menunjukkan bahwa tidak ada kesimpulan yang pasti data tidak mengandung gejala autokorelasi karena dU $(1,78137)<\mathrm{dw}(1,870)<4-\mathrm{dU}(2,21863)$, sehingga layak digunakan untuk memprediksi hubungan antar variabel.

Uji multikolinearitas bertujuan untuk menguji apakah model regresi ditemukan adanya korelasi antar variabel bebas atau independen. Multikolinearitas dapat dilihat dari nilai tolerance atau variance inflation factor (VIF). Nilai cutoff yang umum dipakai untuk menunjukkan adanya multikulinearitas adalah nilai tolerance d" 0.10 atau sama dengan nilai VIF e" 10 . Jika nilai tolerance $>0,10$ atau VIF $<10$ dikatakan tidak ada multikolinearitas (Ghozali, 2009: 95). Dari hasil uji pada Tabel 4 dapat dicermati bahwa model regresi yang terbentuk tidak menunjukkan gejala multikolinearitas. Ketiadaan gejala ini ditunjukkan dari nilai VIF $<10$ dan tolerance $>0,1$.

Uji heteroskedastisitas bertujuan untuk mengetahui apakah variabel yang dioperasikan sudah mempunyai varian yang sama (homogen) atau sebaliknya (heterogen). Model regresi yang baik adalah yang homokedastisitas atau tidak terjadi heteroskedastisitas. Uji heteroskedastisitas dilakukan dengan uji glejser. Jika nilai signifikansinya lebih besar dari 0,05 maka dikatakan model bebas dari heteorkedastisitas (Ghozali, 2009: 125). Tabel 5 menunjukkan bahwa kelima variabel tidak menunjukkan nilai yang signifikan (probabilitas signifikan lebih besar dari 0,05). Jadi dapat disimpulkan bahwa tidak terjadi gejala heteroskedastisitas pada model.

Analisis regressi dengan menggunakan program SPSS dilakukan dalam penelitian ini untuk menganalisis bagaimana pengaruh good corporate governance mechanism (yang terdiri dari lima variabel: kepemilikan manajerial, kepemilikan institusional, proporsi komisaris independen, 
ukuran dewan komisaris dan komite audit) terhadap nilai perusahaan pada perusahaan yang terdaftar dalam indeks LQ45 di BEI. Hasil analisis regresi linear berganda untuk pengujian hubungan antar variabel dalam penelitian ini secara lengkap dapat dilihat pada Tabel 6 .

Hasil analisis menunjukkan bahwa variabel kepemilikan manajerial memiliki koefisien regresi bertanda positif sebesar 0,066 dengan $\mathrm{p}>0,10$. Hal ini berarti bahwa kepemilikan manajerial tidak berpengaruh secara signifikan terhadap nilai perusahaan pada perusahaan yang terdaftar pada indeks LQ45 di BEI. Hasil ini tidak mendukung hipotesis pertama $\left(\mathrm{H}_{1}\right)$ yang menyatakan bahwa kepemilikan manajerial berpengaruh positif signifikan terhadap nilai perusahaan. Kepemilikan manajerial berpengaruh positif namun tidak signifikan pada peningkatan atau penurunan nilai perusahaan.

Tanda positif koefisien regresi kepemilikan manajerial menunjukkan bahwa ketika suatu perusahaan memiliki tingkat kepemilikan manajerial yang lebih tinggi, maka terjadi peningkatan pada nilai perusahaan. Semakin meningkatnya kepemilikan manajerial pada suatu perusahaan, maka para manajemen perusahaan yang juga sebagai pemegang saham akan lebih aktif untuk mewujudkan tujuan perusahaan untuk memaksimalkan nilai perusahaan. Hal ini berarti penerapan kepemilikan manajerial diperlukan perusahaan untuk membantu mencapai tujuan perusahaan yaitu memaksimalkan nilai. Namun, hasil yang tidak signifikan dalam penelitian ini tidak mendukung temuan penelitian yang terdahulu oleh Susanti et al (2010) dan Sofyaningsih dan Hardiningsih (2011) yang membuktikan bahwa kepemilikan manajerial berpengaruh positif dan signifikan terhadap nilai perusahaan. Hal ini kemungkinan terjadi karena tidak banyak perusahaan terindeks LQ45 di BEI yang menerapkan kepemilikan manajerial.

Hasil analisis menunjukkan bahwa variabel kepemilikan institusional memiliki koefisien regresi bertanda positif sebesar $0,549(\mathrm{p}<0,10)$. Arah yang positif menunjukkan bahwa semakin tinggi kepemilikan institusional suatu perusahaan, maka nilai perusahaan cenderung meningkat. Hasil penelitian ini mendukung hipotesis kedua $\left(\mathrm{H}_{2}\right)$ yang menyatakan bahwa kepemilikan institusional berpengaruh positif signifikan terhadap nilai perusahaan yang terdaftar pada indeks LQ45 di
BEI. Hal ini berarti peningkatan atau penurunan kepemilikan institusional berpengaruh terhadap peningkatan atau penurunan nilai perusahaan.

Salah satu penerapan good corporate governance dari segi ownership structure adalah kepemilikan institusional. Kepemilikan institusional mencerminkan proporsi saham perusahaan yang dimiliki oleh institusi atau lembaga, seperti bank, perusahaan asuransi, perusahaan investasi atau institusi lainnya. Tingkat kepemilikan institusional yang tinggi akan menciptakan usaha pengawasan yang lebih besar oleh pihak investor institusional, sehingga dapat menghalangi perilaku opportunistic manajer. Semakin tinggi tingkat kepemilikan institusional maka semakin kuat tingkat pengendalian yang dilakukan oleh pihak eksternal terhadap perusahaan sehingga agency conflict yang terjadi di dalam perusahaan akan semakin berkurang dan nilai perusahaan akan semakin meningkat. Hasil penelitian ini mendukung secara teoritis bahwa ketika perusahaan memiliki kepemilikan institusional yang tinggi, maka nilai perusahaan cenderung meningkat. Temuan ini mendukung hasil penelitian yang dilakukan oleh Nuraina (2012), Fauzan (2012) dan Sukirni (2012).

Hasil analisis menunjukkan bahwa variabel proporsi komisaris independen memiliki koefisien regresi bertanda negatif sebesar $-0,106(p>0,10)$. Hal ini menunjukkan bahwa proprosi komisaris independen tidak berpengaruh secara signifikan terhadap nilai perusahaan pada perusahaan yang terdaftar di indeks LQ45 BEI. Hasil ini tidak mendukung hipotesis ketiga $\left(\mathrm{H}_{3}\right)$ yang menyatakan bahwa proporsi komisaris independen berpengaruh positif signifikan terhadap nilai perusahaan. Proporsi komisaris independen berpengaruh negatif namun tidak signifikan pada peningkatan atau penurunan nilai perusahaan.

Penerapan good corporate governance mechanism juga dapatdilihat dari proporsikomisaris independen pada suatu perusahaan. Ketika suatu perusahaan memiliki proporsi komisaris independen yang lebih tinggi, dewan komisaris akan mampu untuk melakukan pengawasan dan memberikan nasihat kepada dewan direksi secara lebih efektif karena komisaris independen bekerja dengan professional. Oleh karena itu, semakin meningkatnya proporsi komisaris independen pada perusahaan, akan membantu manajemen perusahaan untuk berkinerja dengan lebih baik 
sehingga nilai perusahaan pun meningkat. Namun, hasil yang berbeda ditampilkan pada penelitian ini. Penelitian ini menemukan pengaruh negatif yang tidak signifikan antara proporsi komisaris independen terhadap nilai perusahaan. Hasil ini menyiratkan bahwa proporsi komisaris independen yang terlalu tinggi pada suatu perusahaan menjadi tidak efektif. Hasil yang tidak signifikan pada penelitian ini tidak mendukung hasil penelitian terdahulu oleh Machfoedz (2006) dan Kumar dan Singh (2012), yang menunjukkan bahwa proporsi komisaris independen berpengaruh positif dan signifikan terhadap nilai perusahaan.

Hasil analisis menunjukkan bahwa variabel ukuran dewan komisaris memiliki koefisien regresi bertanda positif sebesar $0,015(\mathrm{p}>0,10)$. Hal ini menunjukkan bahwa ukuran dewan komisaris tidak berpengaruh secara signifikan terhadap nilai perusahaan pada perusahaan yang terdaftar di BEI. Hasil ini tidak mendukung hipotesis keempat $\left(\mathrm{H}_{4}\right)$ yang menyatakan bahwa ukuran dewan komisaris berpengaruh positif signifikan terhadap nilai perusahaan. Ukuran dewan komisaris independen berpengaruh positif namun tidak signifikan pada peningkatan atau penurunan nilai perusahaan.

Tanda positif pada koefisien regresi ukuran dewan komisaris, menunjukkan bahwa ukuran dewan komisaris perusahaan yang lebih besar memiliki kecenderungan peningkatan nilai perusahaan. Dewan komisaris memiliki tugas untuk melakukan pengawasan dan memberikan nasihat kepada dewan direksi. Ketika perusahaan memiliki ukuran dewan komisaris lebih tinggi, maka dewan komisaris akan mampu untuk melaksanakan tugas pengawasan dengan lebih baik, sehingga manajemen perusahaan akan memiliki kinerja lebih baik dan pada nantinya nilai perusahaan dapat meningkat. Namun, hasil yang tidak signifikan dalam penelitian ini tidak mendukung temuan penelitian yang terdahulu oleh Siallagan dan Machfoedz (2006) dan Siahaan (2013) yang membuktikan bahwa ukuran dewan komisaris berpengaruh positif dan signifikan terhadap nilai perusahaan. Hal ini kemungkinan terjadi karena ukuran dewan komisaris bukan faktor pendorong utama dalam mempengaruhi nilai perusahaan pada perusahaan terindeks LQ45 di BEI.

Hasil analisis menunjukkan bahwa variabel komite audit memiliki koefisien regresi bertanda negatif sebesar $-0,122(p>0,10)$. Hal ini menunjukkanbahwakomiteaudittidakberpengaruh secara signifikan terhadap nilai perusahaan pada perusahaan yang terdaftar di indeks LQ45 BEI. Hasil ini tidak mendukung hipotesis kelima $\left(\mathrm{H}_{5}\right)$ yang menyatakan bahwa komite audit berpengaruh positif signifikan terhadap nilai perusahaan. Komite audit berpengaruh negatif namun tidak signifikan pada peningkatan atau penurunan nilai perusahaan.

Secara teoritis dan hasil penelitian terdahulu, telah disusun hipotesis bahwa komite audit berpengaruh secara positif dan signifikan terhadap nilai perusahaan. Namun, hasil penelitian yang dilakukan pada perusahaan yang terdaftar dalam indeks LQ45 di BEI menunjukkan bahwa semakin tinggi jumlah anggota komite audit perusahaan, maka ada kecenderungan nilai perusahaan menurun. Hal ini kemungkinan disebabkan karena sebagian besar perusahaan yang terdaftar dalam indeks LQ45 di BEI memiliki anggota komite audit berjumlah 3 orang, ketika perusahaan memiliki komite audit yang berjumlah lebih dari 3 orang maka tidak akan memberikan manfaat yang lebih besar bagi perusahaan dalam rangka peningkatan nilai perusahaan. Hasil penelitian ini menemukan adanya hubungan negatif yang tidak signifikan antara komite audit dan nilai perusahaan, dimana hasil ini tidak mendukung penelitian terdahulu oleh Siallagan dan Machfoedz (2006) dan Animah (2008).

\section{SIMPULAN DAN SARAN}

Tujuan penelitian ini adalah untuk menganalisis bagaimana pengaruh good corporate governance mechanism terhadap nilai perusahaan pada perusahaan yang terdaftar dalam indeks LQ45 di BEI pada tahun 2016. Berdasarkan hasil analisis regresi linier berganda, dapat disimpulkan bahwa variabel kepemilikan institusional merupakan faktor yang paling berpengaruh terhadap nilai perusahaan. Kepemilikan institusional berpengaruh positif dan signifikan terhadap nilai perusahaan. Sedangkan keempat faktor lainnya yaitu kepemilikan manajerial, proporsi komisaris independen, ukuran dewan komisaris dan komite audit tidak berpengaruh secara signifikan. Kepemilikan institusional memiliki pengaruh yang positif dan signifikan terhadap nilai perusahaan pada perusahaan yang terdaftar dalam indeks LQ45 di BEI dengan tingkat signifikansi 1\%. Hasil penelitian ini mampu memberikan bukti yang kuat bahwa penerapan good corporate governance 
mechanism, dari segi ownership structure yaitu kepemilikan institusional, dapat meningkatkan nilai perusahaan. Semakin tinggi tingkat kepemilikan institusional pada suatu perusahaan, maka semakin kuat tingkat pengendalian yang dilakukan oleh pihak eksternal terhadap perusahaan sehingga agency conflict yang terjadi di dalam perusahaan tersebut akan semakin berkurang dan nilai perusahaan pun akan semakin meningkat. Keterbatasan dalam penelitian ini adalah kecilnya jumlah observasi karena menggunakan crosssection data, sehingga penelitian selanjutnya disarankan untuk memperpanjang periode analisis.

\section{REFERENSI}

Adams, R.B., and Ferreira, D. 2007. A Theory of Friendly Boards. Journal of Finance, Vol. 62(1), pp. 217-250.

Animah dan Ramadhani, R.S. 2008. Pengaruh Struktur Kepemilikan, Mekanisme Corporate Governance dan Ukuran Perusahaan Terhadap Nilai Perusahaan. Tesis dipublikasikan. Universitas Hasanudin, Makasar.

Baek, J.S., Kang, J.K., dan Park, K.S. 2004. Corporate Governance and Firm Value: Evidence from the Korean Financial Crisis, Journal of Financial Economics, 71(2004), pp.265-313.

Bebchuk, L., Cohen, A. dan Ferrell, A., 2009. What matters in corporate governance? Review of Financial Studies, Vol. 22, pp. 783-827.

Brealey, R., Myers, S. dan Marcus, A. 2008, Dasar-Dasar Manajemen Keuangan Perusahaan, Edisi 5, Erlangga, Jakarta.

Brigham, E.F. dan Houston, J.F. 2011. Dasar-dasar Manajemen Keuangan, Edisi 11, Penerjemah Ali Akbar Yulianto, Salemba Empat, Jakarta.

Bruno, V. dan Claessens, S., 2010. Corporate Governance and Regulation: Can There be too Much of a Good Thing? Journal of Financial Intermediation, Vol.19, pp. 461-482.
Brickley, J. A., Lease, R. C., Smith Jr., C. W. 1988, Ownership structure and voting on antitakeover amendments, Journal of Financial Economics, Vol.20, pp. 267-91.

Chhaochharia, V., Laeven, L., 2009. Corporate Governance Norms and Practices. Journal of Financial Intermediation, Vol.18, pp. 405-431.

Chung, K.H., Pruitt, S.W. 1996. A Simple Approximation of Tobin's Q. Financial Management, Vol.23(3), pp.70-74.

Cremers, M. dan Nair, V.B., 2005. Governance mechanisms and equity prices. Journal of Finance, Vol.60, pp. 2859-2894.

Creswell, J.W. 2014. Research Design, Qualitative, Quantitativem and Mixed Methods Approaches. USA: Sage Publications, Inc.

Core, J., Guay, W.R. dan Rusticus, T.O., 2006. Does weak governance cause weak stock returns? An examination of firm operating performance and investors' expectations. Journal of Finance, Vol. 61, pp. 655-687.

Daniri, M.A. 2005. Good Corporate Governance Konsep dan Penerapannya dalam Konteks Indonesia. Jakarta, Ray Indonesia.

Debby, J.F., Mukhtaruddin, Yuniarti, E., Saputra, D. dan Abukosim. Good Corporate Governance, Company's Characteristics and Firm's Value: Empirical Study of Listed Banking on Indonesian Stock Exchange. GSTF Journal on Business Review (GBR), Vol.3(4), pp.81-88

Eberhart, R. 2012. Corporate Governance Systems and Firm Balue: Empirical Evidence from Japan's Natural Experiment. Journal of Asia Business Studies, Vol.6,No.2.

Fairchild, L. dan Li, J. 2005. Director Quality and Firm Performance. The Financial Review, Vol. 40(2), pp. 257-279.

Ghozali, Imam. 2013. Aplikasi Analisis Multivariate dengan Program IBMSPSS 21, 
Edisi 7. Semarang: Badan Penerbit Universitas Diponegoro.

Gompers, P.A., Ishii, J., Metrick, A., 2003. Corporate Governance and Equity Prices. Quarterly Journal of Economics. Vol.118, 107-155.

Gujarati, D.N., and Porter, D.C. 2009. Basic Econometrics (fifth edition). Boston: McGraw-Hill International Edition.

Gujarati, D.N. 2011. Econometrics By Example. New York: Palgrave Macmillan.

Hair, J.F., Balck, W.C., Babin, B.J., Anderson, R.E., and Tatham, R.L. 2006. Multivariate Data Analysis (sixth edition). New Jersey: Prentice Hall.

Hanafi, M.M. 2014. Manajemen Risiko, Edisi Ketiga, Yogyakarta: UPP STIM YKPN.

Horne, J.C.V. and Wachowicz Jr., J.M. 2012. Fundamentals of Financial Management. $13^{\text {th }}$ Edition. England: Pearson Education Limited.

Husnan, S. 2008. Manajemen Keuangan: Teori dan Penerapan Buku 1, Edisi 4, Yogyakarta: BPFE

Jensen, M.C., Meckling, W.H. 1976. Theory of the Firm: Managerial Behavior, Agency Costs and Ownership Structure, Journal of Financial Economics, Vol.3 (October 1976), pp.305-360.

Jensen, M., Murphy, K. 1990. Performance pay and top management incentives. Journal of Political Economy, Vol.98, pp.225-264.

Keown, A.J., David F.S.Jr., John, D.M, Petty, J.M. 2011. Manajemen Keuangan (prinsipprinsip dan aplikasi). Jakarta Barat: PT indeks kelompok Gramedia.

Kumar, N. dan Singh, J.P. 2012. Outside Directors, Corporate Governance and Firm Performance: Empirical Evidence from India. Asian Journal of Finance \&
Accounting, Vol.4(2), pp.39-55.

Machfoeds, M. 2011. Board Duties Lembaga Komisaris dan Direktur Indonesia. LKDI: Jakarta.

Mishra, S. dan Mohanty, P. 2014. Corporate Governance As a Value Driver for Firm Performance: Evidence from India, Corporate Governance, Vol.14(2), pp. $265-280$

Nuraina, E. 2012. Pengaruh Kepemilikan Institusional Dan Ukuran Perusahaan Terhadap Kebijakan Hutang Dan Nilai Perusahaan (Studi Pada Perusahaan Manufaktur Yang Terdaftar Di BEI). Jurnal Bisnis dan Ekonomi (JBE). Vol. 19, No. 2 September 2012.

OECD. 2014. Risk Management and Corporate Governance, Corporate Governance, OECD Publishing.

Osuoha J. 2013. Financial engineering, corporate governance and Nigeria economic development. Journal of Financial Risk Management, Vol. 2(4), pp. 61-66. Scientific Research Publishers, (SCIRP) United States of America.

Renders, A. dan Gaeremynck, A. 2012. Corporate Governance, Principal-Principal Agency Conflicts and Firm Value in European Listed Companies. Corporate Governance: An International Review, Vol.20(2), pp. $125-143$

Sartono, A. 2010. Manajemen Keuangan Teori dan Aplikasi. Edisi Keempat. Yogyakarta: BPFE.

Saunders, M., Lewis, F., Thornhil, A. 2016. Research Methods for Business Students, Italy: Pearson Education

Salvatore, D, 2005. Managerial Economic : Ekonomi Manajerial dalam Perekonomian Global. Edisi Kelima. Terjemahan Ichsan Setyo Budi. Penerbit Salemba Empat. Jakarta 
Siahaan, F.O.P. 2013. The Effect of Good Corporate Governance Mechanism, Leverage and Firm Size on Firm Value. GSTF International Journal on Business Review (GBR), Vol.2(4), pp.137-142

Siallagan, H. dan Machfoedz, M. 2006. Mekanisme Corporate Governance, Kualitas Laba dan Nilai Perusahaan. Simposium Nasional Akuntansi IX. Padang

Sofyaningsih, S. dan Hardiningsih, P. 2011. Struktur Kepemilikan, Kebijakan Dividen, Kebijakan Utang Dan Nilai Perusahaan. Jurnal Akuntansi Universitas Stikubank. Vol. 3 No. 1 ISSN :1979-4878.

Sugiarto, M. 2011. Pengaruh Struktur Kepemilikan Dan Kebijakan Dividen Terhadap Nilai Perusahaan Dengan Kebijakan Hutang Sebagai Intervening. Jurnal Akuntansi Kontemporer, Vol. 3 No. I Januari 2011.

Sukirni, D. 2012. Kepemilikan Manajerial, Kepemilikan Institusional, Kebijakan Deviden Dan Kebijakan Hutang Analisis Terhadap Nilai Perusahaan. Jurnal Universitas Negeri Semarang Vol 1 No 2 Tahun 2012.
Susanti, A.N., Rahmawati., dan Aryani, A. 2010. Analisis Pengaruh Mekanisme Corporate Governance Terhadap Nilai Perusahaan dengan Kualitas Laba Sebagai Variabel Intervening pada Perusahaan Manufaktur yang Terdaftar di Bursa Efek Indonesia Periode 2004-2007. SImposium Nasional AKuntansi X. Makasar.

Sutojo, S. dan Altridge, E. J. 2008. Good Corporate Governance - Tata Kelola Perusahaan yang Sehat. Jakarta, Damar Mulia Pustaka.

Susanti, R. 2014. Pengaruh Kepemilikan Manajerial, Kepemilikan Institusional Dan Corporate Social Responsibility Terhadap Nilai Perusahaan. Jurnal Sekolah Tinggi Ilmu Ekonomi Indonesia (STIESIA) Surabaya. Jurnal Ilmu \& Riset Akuntansi Vol. 3 No. 1 Tahun 2014.

Sutojo, S. dan Altridge, E. J. 2008. Good Corporate Governance - Tata Kelola Perusahaan yang Sehat. Jakarta, Damar Mulia Pustaka.

Trinh, T.H., Duyen, T.T.T., Thao, N.T. 2015. The Impact of Corporate Governance on Financial Risk in Vietnamese Commercial Banks. International Journal of Economics and Finance, Vol. 7(7), pp. 123-130 